\title{
Keeping science at the core
}

Harvey Brooks

The Education of a College President: A Memoir. By James R. Killian, Jr.

MIT Press: 1985. Pp.478. \$19.95, £19.95.

DURING the middle years of this century. James Killian presided over the transformation of the Massachusetts Institute of Technology from a highly respected engineering school to the world's leading technological university, a "university polarized around science". This last phrase is used by the author to describe an institution embracing virtually all fields of knowledge. but with each discipline in orbit, as it were, around a central nucleus of science and technology. In the same career. Killian intermingled university leadership with high-level public service. notably as science adviser to President Eisenhower and as a key figure in many seminal government advisory groups during a formative period for both science policy and defence policy. What were the experiences and personal qualities that enabled this individual, not himself either a scientist or an intellectual with academic pretensions, to become accepted as a colleague and leader by scientists and scholars, and to become an educational and scientific manager of the first rank? This highly personal, rambling and optimistic memoir does provide some insight into the answers, though it is as interesting for what it leaves out as for what it includes.

A man of broad general cul-

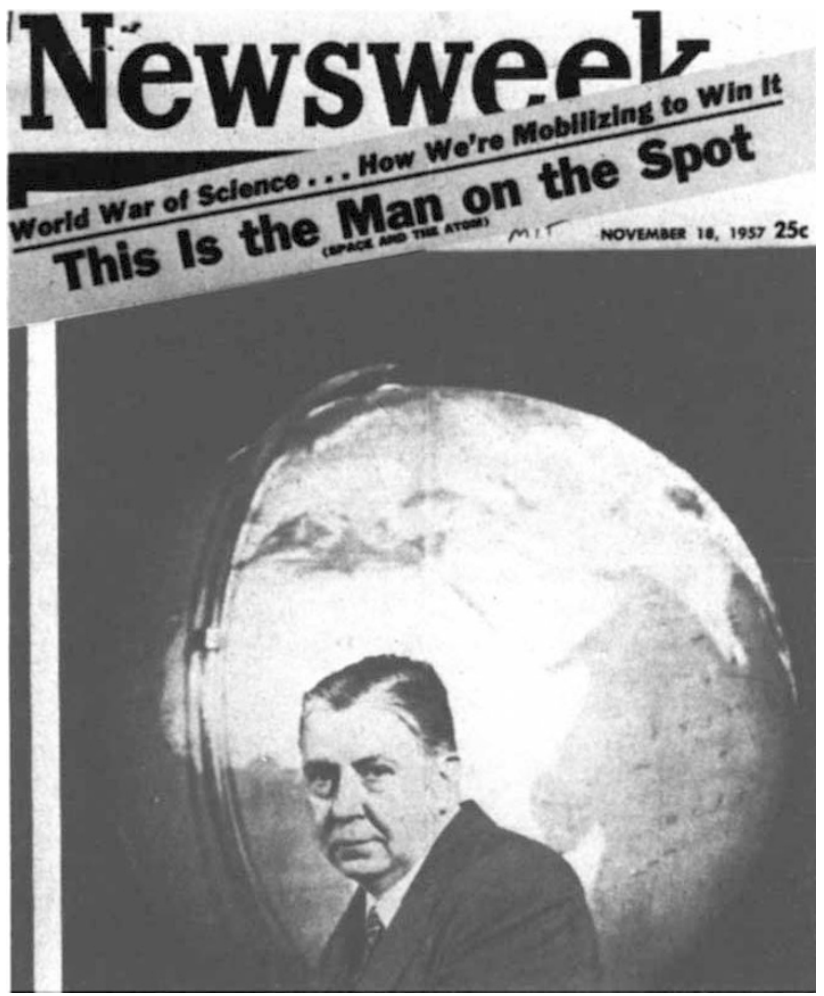

James Killian on the cover of Newsweek. November 181957.

persuade the disciplines to subordinate their parochial interests and claims to academic "turf". Thus he sees MIT as a federal rather than as a feudal system. I suspect one could find a good many people at MIT who would not fully share this view, but I think it is, on average, correct.

Killian cites two revealing anecdotes to illustrate the source of his view of the key importance of consensus-building. Each involved the eventual failure or compromise of a good idea because of a lack of consultation with powerful interests in advance of a public commitment. The first example is an academic one. In 1956, at a public dinner in New York, he announced MIT's intention to establish within its structure a new School of Advanced Study before he had spoken to the appropriate faculty committees or the faculty as a whole. From the incident he drew a lasting lesson that "no new programs or buildings large in costs should be undertaken, however innovative, without the knowledge and advice of appropriate faculty groups" (p.138). In this instance, what he still obviously feels was an excellent idea had to be abandoned.

-A parallel example on the national stage occurred soon after Killian had become science adviser to Eisenhower. In 1958, on the basis of the technical findings of the President's Science Advisory Committee, communicated to him by Killian, Eisenhower wrote to Kruschev suggesting that a comprehensive nuclear test ban agreement was negotiable, and proposing the convening of a panel of technical experts to agree upon the design of an international detection system capable of ensuring against clandestine testing ture, boundless intellectual curiosity and catholic interests, very "people oriented" though not remarkably gregarious, Killian became dedicated through an unusually varied apprenticeship to "developing creative integration and interdisciplinary congeniality among a variety of research fields", and he applied an extraordinary talent for consensus-building among diverse and strong-minded individuals in both academic and political settings. He was obviously a good listener with a capacity for extracting a practical synthesis out of the ideas of creative people. Not an obvious originator himself, and lacking a strong pride in authorship, he nonetheless had a talent for recognizing people with original ideas and enabling them to realize their visions.

His success in these endeavours was reinforced by what he describes as his "clinging to a melioristic view that our future is best served by an acceptance of what $\mathrm{Sir}$

helping brilliant - often cranky and egotistical - people to sell themselves and their ideas, and he believed this could best be accomplished through conscientious and patient consultation.

Insofar as MIT was concerned, Killian rejects Clark Kerr's pessimistic view of the modern "multiversity" impervious to structural change, the advocate of change for every part of society except itself. The MIT he knew originated and assimilated many structural improvements, including new interdisciplinary laboratories, curriculum reform, undergraduate research, a new management school, new departments in the humanities and social sciences, a joint school of health sciences and technology with Harvard, and many other institutional innovations. MIT, Killian feels, has avoided the usual "hang-ups" of the multiversity by combining a single unified faculty with a strong, but accessible, style of presidential leadership, able to especially underground testing - by any nation. The President's initiative, however, was taken without internal consultation with the Department of Defense, The Atomic Energy Commission or the Central Intelligence Agency.

Of the technical discussions, led on the American side by Dr James B. Fisk. President of Bell Laboratories, Killian says: "Dr. Fisk and I agreed that at no subsequent negotiation with the Soviets on arms limitation had the Soviets expressed such willingness to accept on-site inspection" (p.281). He implies that the lack of internal consultation in the US government before the Presidential initiative "was to aggravate differences in our own government" which became a major factor in America's inability to negotiate a comprehensive test ban rather than the much more limited atmospheric test ban finally achieved under the Kennedy administration in 1963. As we now know, the 
rapid evolution of a sophisticated technology for underground tests largely offset the constraints on weapons development posed by the ban on atmospheric testing, and really only served to drive nuclear weapons development underground literally and figuratively - and out of the public eye. Whether prior consultation would have merely tied the hands of the technical negotiators rather than leading to a stronger diplomatic agreement is a matter of opinion. But again, Killian's account of this episode illustrates the high importance which he attached to the building of consensus among divergent interests as a prerequisite for action (p. 279).

Although Killian's assessment of the achievements of the modern research university is highly positive, and in many

the quality of engineering and is this in turn a consequence of deterioration in the standards of engineering education? Were the reforms of the engineering curriculum to make it more "scientific" and general, which Killian obviously endorses, implicated in the problem, as some people are now asserting? Did the American preoccupation with originality, creativity and individual competitive achievement somehow result in neglect of meticulous workmanship and attention to the more routine and mundane aspects of engineering, which are so crucial to the quality and reliability of technological products? Did the great research universities, in their pursuit of a particular cultural concept of "excellence", provide an inappropriate model for the mass of the engineering and technical professions?

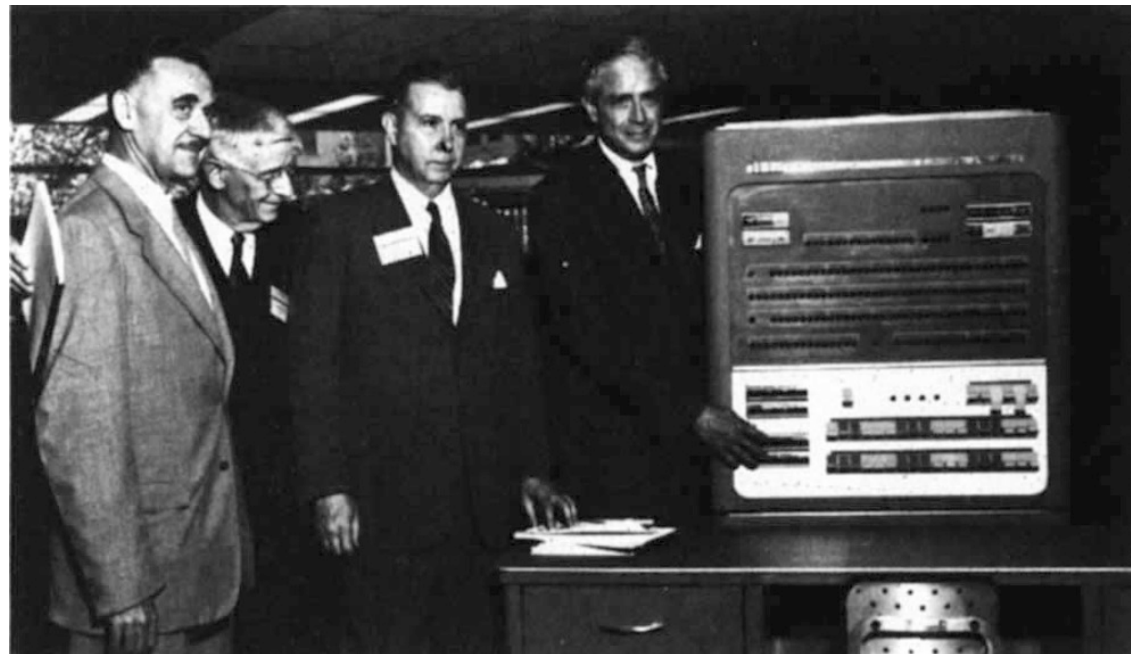

James Killian (second from right) with Philip Morse, Vannevar Bush and Thomas J. Watson dedicate MIT's first major computational centre in 1957

ways forms the leitmotif for his whole memoir, he does concede some shortfalls and failures; however, he makes little effort to analyse the possible reasons for them. For example, while he is proud of MIT's success in creating interdisciplinary laboratories and in fostering other kinds of creative work across conventional intellectual boundaries, he admits that MIT's efforts "have not succeeded in demonstrating how these fields necessarily interact with each other and how this diverse learning is comprehended in indivisibility" (p. 402). Somehow his "enlarged vision of the place" has not quite been achieved. Yet he never even speculates as to the reasons why this might have been so

\section{More seriously, he suggests that}

the universitics cannot wholly disclaim responsibility for an unmistakable decline in the quality of everyday life as so frequently reflected in American craftsmanship. in the unreliability of too much of our technology, and in the low quality of many consumer products and their service $[p .410]$.

This is an intriguing statement. which is simply left hanging. In what way or in what sense are the universities responsible? Does the situation reflect a decline in
Another intriguing area of ambivalence in Killian's account of the era he describes has to do with the role of the "militaryindustrial complex". On the one hand, the whole memoir is full of pride in the services of MIT and its staff (including Killian himself) to the nation in matters of national security - the series of interdisciplinary studies organized by MIT in the 1950s, the creation of the Lincoln Laboratory, the accomplishments of the Instrumentation Laboratory (now divested from MIT as the Draper Laboratory). Project Whirlwind, the Servomechanisms Laboratory and so on. On the other hand, he makes frequent references to the dangers of militarization, stating in one place that "the military-industrial complex ... is still having a profoundly dangerous impact on our government" (p. 419). Even his "hope of progress" is "tempered by fear of nuclear war and of an intemperate militaristic spirit eroding the most precious values of our society" (p.415)

These are strong words, but just who is the military-industrial complex? Many of the basic technological advances that have helped fuel the arms race have emerged from the large government-financed laboratories managed and operated by some of our great research universities - for example, the concept of multiple independently targeted re-entry vehicles and dramatic advances in missile guidance accuracy that emerged from the MIT Instrumentation Laboratory, and the high yieldto-weight thermonuclear weapons which were developed in the two weapons laboratories of the University of California. While praising the scholars from research universities who "have been speaking with knowledge, integrity, and responsibility about nuclear issues" (p.419), Killian never quite comes to grips with what the proper role of the research universities should be in relation to the creation of military technology or even the science underlying it. Should research universities, for example, pick and choose which governmental demands they respond to according to some collective view of their potential effect upon the arms race? What would be the implications for academic freedom of the enforcement of such a collective sense of responsibility on their individual members? To what extent would such institutional self-denial decrease the capacity of academics to speak out with real knowledge and responsible criticism in the national debates over defence poli$c y$, and leave the field to those with greater vested interests than the universities? These issues have never been posed to the universities in starker form than by the current Strategic Defence Initiative; it would have been interesting to have had Killian's views as to how his favourite institutions should come to grips with this new challenge to their role.

The sanguine tone of this memoir sometimes borders on the polyanna-ish. It is striking that, although there are interesting personal sketches of many of the principal actors in the development of America's post-war science and defence policies, villains are notable by their absence. Admiral Lewis Strauss of the Atomic Energy Commission is virtually the only important personality even mentioned in unfavourable terms, and even here the strictures are remarkably restrained. The vehement denunciations of the militaryindustrial complex are notable for their lack of specificity, and the reader is left in the dark as to which institutions and groups qualify for this pejorative label. and what sorts of behaviour take them over the line from patriotism to villainy. Lobbying of the political process on behalf of funding for particular weapons systems seems to be the only identified behaviour which is beyond the pale, yet one must also ask how these activities are to be distinguished from the various "summer studies" and high-level commissions (such as the Technological Capabilities Panel. which Killian himself chaired) which were the genesis of many new weapons systems.

Harvey Brooks is Benjamin Peirce Professor of Technology and Public Policy, John F Kennedy School of Government, Harvard Uni versity, Cambridge, Massachusetts 02138, USA. 